\title{
Analysis on Vocational College Students' Employment Psychological Problems and Employment Guidance Strategy
}

\author{
Zhang Guojing \\ Liaoning Urban Construction Technical College \\ Shenyang, Liaoning, 110122 China
}

\begin{abstract}
Facing the current employment situation of the independent choosing and Two-way choice and the severe employment situation, the article analyzed college students' the employment psychological problems and what cause this reason, according to the psychological problems of graduates and the actual situation of colleges, Propose strategies of implement the full program of career guidance for the college students, to help students correct attitude, Establish a correct outlook on life and values, enhance the occupation ability, enhance the employability and competitiveness, and constantly improve the employment rate and employment stability factor of the school.
\end{abstract}

Keywords-graduates; employment; Psychological problems; Employment guidance;

\section{Introduction}

Lu Xin, Vice Minister of Education Ministry pointed out in newly increasing labor supply and demand, in recent years, the total amount of labor market in China is about $17,000,000$ people every year, and 7,000,000 people are graduates from secondary vocational colleges, and $7,000,000$ people are high education graduates. So, higher vocational education and ordinary undergraduates are each half. That is to say, graduates in vocational colleges occupy most of the number of labor market. Then how to improve vocational college students' vocational ability is to improve students' an employment rate and employment-oriented rate.

Thus, understanding vocational college graduates' employment psychology, grasping vocational college students' employment trend and making scientific, reasonable employment and selection guidance in time are effective means of ensuring graduates's mooth employment.

\section{Common Employment Psychological Problems of Vocational College Students}

\section{(1)Dependence Psychology}

Dependence psychology refers to that, in employment process, it focuses too much on insufficient social experience, leading independent consciousness shortage, without independent employment and selection ability [1]. Some graduates are not active to understand major development status and social talent demand situation in employment process. They are not active to contact the employer units, and they put all their employ ment hope on their schools or relatives and friends. Their competition consciousness and participation sense are very weak, and still some students need their family, classmates and friends for accompany in finding jobs. They cannot independently participate in the job interview or unit interview.

\section{(2)Conceit Psychology}

Conceit psychology is that graduates' expectation for themselves are higher than their actual ability level. Some students evaluate too much on themselves. They think of themselves as "God favored one", and they cannot make objective and accurate positioning for themselves. This conceit psychology leaves an impression "prospect higher and lower ability" on employers, excluded by employ ment units, resulting in the result of "not employed".

\section{(3)Inferiority Psychology}

Inferiority psychology and conceited psychology are totally opposite, which are excessive self-denial. These students emphasize too much on their low academic education, cold majors and weak comprehensive quality, 
and they think their professional level is poor, far away from undergraduates. Employers will first select undergraduates, and in this pessimistic psychology, they will underestimate their knowledge level and ability level, lacking of self-confidence on employment.

\section{(4)Herd Psychology}

Herd psychology is a common mental phenomenon. It refers to that before making judgment, they will get more influence by external factors. [2]Graduates' herd psychology is before graduation, and they cannot be active to understand social talent demand situation, making objective analysis of their own actual situation, ignoring their own interests, hobbies and vocational ability. They blindly listen to their family and friends' suggestions. These students will often follow others' steps, divorced from reality in employment, so as to miss their own vocational development opportunities.

\section{(5)Comparison and Vanity Psychology}

Comparison and vanity psychology is a character flaw of pursuing virtual surface. In market economy condition, by money worship and hedonism thought influence, some students focus on economic income in employ ment process, and some graduates see their classmates and friends' salaries are higher than theirs in the value guidance of "people upwards", they will think that they are not worse the others. Thus, they blindly resign, make job hopping and seek for higher employment goal. This comparison psychology makes their employment unstable.

\section{Employment Psychology Problem Reason of Vocational College Graduates}

\section{(1)Subjective Factors}

\section{1) Inferior Overall Quality}

In the public opinion of "good performance for better jobs", some students go to vocational colleges helplessly. In the negative mental effect of failure in college entrance examinations, their learning enthusiasm is poor and professional knowledge is not solid. Practical ability is not strong, with weak vocational quality. Their social responsibility sense is not strong, making them not confident in their future, thus, they have various negative employment psychology [3].

\section{2) Employment View and Selection View Have Deviation.}

In the process of employment selection, graduates have deviation of self-evaluation and self-cognition, making their employment view unclear. They are not active to understand employ ment information, employ ment situation, employment policy and social talent demand information. They don't make contact with their own actual situation and social talent demand. So in employment, they have blindly optimistic or conformity and ego psychology.

\section{3) Weak Competition Consciousness}

In two-way selection and independent employment form, some graduates in vocational colleges have not established correct vocational ambition, lacking of enough employ ment psychology preparation. Facing severe employment situation, they cannot adjust their employment psychology in time, and their parents care and love them too much. Parents do too much for them, and this long-term dependence habits make them have poor employment initiative, lacking of competition consciousness.

\section{(2)Objective Factors}

\section{1)Social Factors}

During " $12^{\text {th }}$ five year plan" period, industrial structure in China makes constant adjustment, and some low value-added and low technical content labor-intensive enterprises are gradually changing to high value-added and high technical content technology-intensive enterprise. Technical workers and first-line workers are needed tightly, but graduates are influenced by employment view and vocational ambition, and they are not willing to work in first-line of enterprises, increasing the supply and demand contradiction of labor market. 


\section{2) School Factors}

In recent years, education department focuses on importance of vocational guidance, but school vocational guidance is not profound, and some vocational colleges don't have complete vocational guidance institutes. Emp loy ment psychology is not professional and not perfect, so many schools have relevant employment policy, selection mentality problem for consulting in the third grade, but most of them are in lecture form, and they cannot make profound guidance, making students have not established correct emp loyment view after graduation. They don't have a clear understanding for interview skills, so as to have blind and confusion and other negative mental factors.

\section{3) Family Factors}

Due to parents' excessive doting for children, high score and low ability phenomenon often appears. Even some parents accompany in children's job interview, some parents recruit resumes for their children. Some parents find relationship to arrange children's employment, so as to make graduates' employment have strong dependence and their anti-frustration ability declines. After they go to work, they have poor interpersonal relationship and they are not capable of their work.

\section{Employment Guidance Strategy of Vocational College Students}

In the face of two-way choice and independent selection and other employment policies and severe employment situation, vocational colleges should make overall employment guidance for students, namely, in the beginning, we can help students to make employment mental preparation, establishing correct employment view and help them to make reasonable vocational plan design [4].

\section{(1)Guiding Students to Establish Employment Competition Consciousness}

Vocational students, away from college entrance examinations, are excited after entering into college, and they are hard to have a sense of urgency and competition consciousness for after three years' employment situation. Thus, vocational colleges should educate students to correctly understand the employment mechanism of independent employment since the entrance education stage, making them understand that competition can optimize talent allocation. Vocational colleges can use lectures, graduate experience introduction and expanding training mode to lead students to actively participate in competition, cultivating students' competition consciousness and improving their employment sensitivity, in order to make a full mental preparation for their future severe employment situation and fierce employment competition in three years.

\section{(2)Cultivating Students' Vocational Career Design Ability}

Occupation career refers a person's life occupation process, namely the series of roles and positions by a person from initial occupation to final occupation, which is the process of receiving education and implementing training with plan, realizing occupation career goal. Higher vocational stage is the preparation and selection stage of vocational career planning, which has an important role for vocational college students' emp loyment[5]. Thus, since the first year at college, through opening vocational career planning course, lectures and mental counseling mode, it can guide students to objectively analyze their own vocational interest and advantages and they can objectively know the mselves, establishing correct life view, world view and values. Combined with professional and social development demand, they can make rational occupation career planning design, in order to make correct self-occupation career goal[6].

Also, school vocational guidance or employment guidance institutes should actively create favorable conditions for students, encouraging them to use spare time to actively take part in social practice, using practice opportunity to know about practice and internship, making students directly contact the society, experiencing various occupation roles and trying success and failure, in order to cultivate students' perseverance, teamwork, dedication and self-confidence. Also they should properly make 
employment skill guidance, pre-post training, employ ment situation analysis, thus leading students to know clearly about situation, so that they can constantly adjust their employment values and find their own rational positions.

\section{(3)Strengthening Mental Quality Education and Guidance}

Mental quality is an important part of overall quality of humans. Most students have weak anti-frustration ability, and they are easy to produce various employment mental problems. Thus, vocational colleges should set up mental counseling clinics, in order to provide mental counseling for students at any time. In the process of employment guidance, we should guide students to improve their own control ability, correctly treat success and failure in employment process, make conclusion of experience and lessons, constantly strengthen self-mental adjustment, enhance self-confidence, perfect personality and improve environment adaptability, in order to make them keep a good employment attitude and fully display themselves in employment for successfulemployment.

\section{References}

[1] Jiang Bin. Contemporary college students' employment psychology problems and improvement measures[J]Human Resources Management,2014 (03): 169.

[2] Li Yongquan. Influence on employment psychology of college students for employment guidance work[J]Journal of Liaoning Communication College, 2005 (6): 107-108.

[3] Qi Jianyun. Analysis on diversified occupation guidance and city employment coordination development research[J]Journal of North China Institute of Aerospace Engineering, 2014 (1): 162-163.

[4] Liu Yunhua. On role and importance of vocational guidance in high-quality employment[J]Statistics Management,2014 (02): 132-133.

[5] Xiong Yemei. Higher vocational college students' vocational guidance course[M].Beijing: China People's Press,2002: 25.

[6] Sun Li. Countermeasures and suggestions of improving vocational colleges' vocat ional guidance education quality[J]. Henan Education, 2014(02): 12 . 